La

Révolution

française

\section{La Révolution française}

Cahiers de l'Institut d'histoire de la Révolution française

2 | 2012

La presse

\title{
Termometri politici: sciences and politics in encyclopedic journals in Naples in the revolutionary and Napoleonic age
}

\section{Maria Conforti}

\section{OpenEdition}

\section{Journals}

Electronic version

URL: http://journals.openedition.org//rf/517

DOI: $10.4000 /$ Irf.517

ISSN: $2105-2557$

Publisher

IHMC - Institut d'histoire moderne et contemporaine (UMR 8066)

\section{Electronic reference}

Maria Conforti, «Termometri politici: sciences and politics in encyclopedic journals in Naples in the revolutionary and Napoleonic age », La Révolution française [Online], 2 | 2012, Online since 10

September 2012, connection on 21 April 2019. URL : http://journals.openedition.org/lrf/517 ; DOI :

10.4000/Irf.517

This text was automatically generated on 21 April 2019.

(c) La Révolution française 


\title{
Termometri politici: sciences and politics in encyclopedic journals in Naples in the revolutionary and Napoleonic age
}

\author{
Maria Conforti
}

A periodical leaflet must be a political thermometer,
regularly showing the state of the people; from this
point of view, it has a sacred duty, and the efforts of
those working for it deserve public recognition ${ }^{1}$.

1 This definition of journals as political thermometers comes from an article published in 1806 in Naples Giornale Enciclopedico (1806-1821). The metaphor is both medical and political, and shows the persistence, and the revival, of the stereotype of the 'body politic', as well as the awareness of the innovations in clinical medicine and in the sciences. Its author, Raffaele Pepe (1773-1834), was a member of the gentry, and a landowner in the region of Molise. He was a reformer, and in 1799 he had sided with the revolutionary Repubblica; subsequently he had been prosecuted by the Sanfedisti ${ }^{2}$. Here, at the beginning of an article dealing with agriculture, he expands on the duties of a journal towards the body politic ${ }^{3}$. Pepe may have been aware that a journal with the same title, the Termometro politico della Lombardia, had been briefly published in Milan in the revolutionary years, from 1796 to 1797 . He undoubtedly had an interest in journalism: in 1819 he founded a periodical himself, on agriculture - one of the first specialised in the field to be published in the Kingdom of Naples".

In what follows, I will try to show how the 'encyclopedia', the system of organisation of the different sections of knowledge, in the Giornale Enciclopedico and in other journals, reflects political implications, conflicts and tensions in the field of sciences - sciences as intellectual pursuits as well as practices - in the Kingdom of Naples in the years preceding and following the 1799 Revolution. To begin with, I will sketch an introduction to the 
learned journals in Naples at the end of the $18^{\text {th }}$ century and of their political meaning, especially in relation to the promotion of the Provinces of the Kingdom; I will then briefly examine the Giornale Enciclopedico, and the way its headings and sections change, following different patterns of appropriation by individuals and groups acting in the Kingdom - and also following, and indirectly describing, the changes in the wider European classification of sciences and disciplines, as well as the way these were reflected in the Kingdom. My main contention will be that along the comparatively long life of the Giornale medicine acts as a sort of large 'umbrella' comprehending and articulating other scientific fields - mainly because its public (and often its authors) were medics. Soon after its foundation, in the French decade, the acting director of the Giornale, the physicianturned-botanist Michele Tenore, used the journal to support his discipline, to publish his work and to foster projects of developments in the sciences and the industries in the Kingdom. In the late years of the Giornale, with the newly restored Bourbon dynasty, the physician Luigi Chiaverini used the Giornale to promote a new discipline, biologia.

\section{Naples, the Kingdom, and its journals}

Between the end of the $18^{\text {th }}$ and the first decades of the $19^{\text {th }}$ century a number of learned journals, most of them not specialised, was published in Naples and in its Kingdom. In the previous decades, the city had become one of the Italian centres for Enlightenment, also becoming independent after centuries of Spanish (and briefly Austrian) rule ${ }^{5}$. At the end of the century, in 1799, a revolutionary upheaval meant to follow the French model, and conducing to a Repubblica proclaimed by a handful of noblemen and gentlemen, among which some noteworthy women, was brutally ended by Bourbon repression. The city intelligentsia participated in the revolution, as it had participated in the previous abortive projects of reform of the economic and political settings of the Kingdom. A substantial number of Neapolitan medics - physicians and surgeons -, engineers and naturalists fled to Paris and France and studied there, profiting from the post-revolutionary scientific and professional schools ${ }^{6}$. In 1806, following Napoleonic wars, Naples and the Kingdom were allotted to Giuseppe Bonaparte, the Emperor's brother, and then to Joaquim Murat, one of Napoleon's brothers-in-law, thus reinforcing personal and political ties between Naples and France. The generation of skilled professionals and scholars coming back from exile, or finally able to act, cultivated the hope - ultimately shown to be a delusion - of a radical change, both political and intellectual, in the life of the Kingdom. In the first years after the Restoration, with king Ferdinand IV, there was an effort to keep alive institutions and reforms of the previous period, but this drive did not last beyond the 1820s.

4 Naples could be perceived as Europe's extreme border, an ultima Thyle of learning and science; at the same time, it prided on its tradition - which was mainly medical and juridical, and obviously philosophical - and it refused to see itself as merely a 'periphery' of European learned world. A periphery it was not - at least, not in the early 19th century. Indeed, the whole history of Neapolitan learning in the early modern age shows why the dichotomy centre/periphery is so difficult to apply in the real world. While being a center for learning and also, to a certain extent, for scientific knowledge and practice, Naples had no learned journals until quite late in the $18^{\text {th }}$ century - this is a remarkable difference with almost any town or city in Italy at the time. One of the features of the urban landscape in Naples was its printing press industry, flourishing from the $16^{\text {th }}$ to the 
$18^{\text {th }}$ centuries, and even more in the $19^{\text {th }}$. As Anna Maria Rao, among others, has underlined, it is thus a rather surprising feature of the intellectual life in Naples that learned journals began to be published only very late, and in comparatively small numbers ${ }^{7}$. Only at the end of the $18^{\text {th }}$ century - in the wake of the political upheaval - the number of journals increased substantially. This means that the political content and meaning in Neapolitan journals, even those mainly devoted to sciences, is uncommonly important, if compared to the periodicals published in other Italian cities and states ${ }^{8}$. Among the first journals published in the Kingdom, in the 1780s we find the Scelta miscellanea (1783-5) ed. by Giovanni De Silva, and the Giornale Enciclopedico di Napoli (1785-6), ed. by Giuseppe Vairo Rosa (1741-1795); in the 1790s, the Analisi Ragionata de' Libri nuovi (1791-93), ed. by Giovan Leonardo Marugi (1753-1836), followed by the Effemeridi enciclopediche (1794-6) (conservative) and the Giornale letterario di Napoli (1793-1799) (progressive) ed. by Luigi Targioni (1751-?). All were issued monthly. In the same period, almost no specialised journal was published. The preference for 'generalist', or encyclopedic, journals, and the reiterated use of the adjective enciclopedico, clearly has a political meaning.

5 Explanations for the paradoxical delay in journal publishing in the capital and in the Kingdom include the lack of a proper middle class, the presence in the late $18^{\text {th }}$ century of a strong censorship and of a licence system that did not encourage the entrepreneurship in this field ${ }^{9}$. While certainly helpful, to these explanations yet another could be added. Quoting from the 1793 Preface to the Analisi Ragionata:

"Naples does not have a journal. We do not want to say that it deserves one, nor that it needs one. The Provinces do indeed need one: since they are composed by very small towns, the curious and the learned there are extremely isolated. They can only communicate with the rest - not of Europe, nor of Italy, but of the Kingdom itself - by the means of a Journal. Our Journal will thus be the means to transmit to our people what is foreign; our news to our people, and to the foreigners" 10 .

There are at least three elements at play here: Naples, the capital; the Provinces, and the foreign world (one may add a fourth, Italy). Probably, one of the reasons why Naples did not have a journal was that members of the scientific and learned élite in the city had long been used to publish in journals in Italy or abroad, as well as to turn to them for information; on the whole, they had a rather ambivalent perception of their relationship with the 'outside' world, that is, with Italy (an entity that did not yet exist politically) and with foreign countries. In fact, they were seemingly more aware of what happened in the larger European (and Italian) space, than of the difficult life going on in the Provinces, where many of them possessed lands and fiefs, and from where almost all the members of the middling professional class came. This attitude was favoured by centuries of foreign rule, as well as by the cultural and economic backwardness of the Kingdom as a whole.

Beginning with the 1780s, something quite new happened: the Provinces of the Kingdom came to the fore as never before. This was a move encouraged by the moderate reformism shown by the Bourbon court, as well as one of the reasons for the creation of (some) journals ${ }^{11}$, but nature itself triggered the process. In 1783-4 a devastating earthquake almost completely destroyed a great part of the Calabria provinces. Sadly, as it often happens with natural catastrophes, this was a great occasion for scientific observation, and also, in the long run, an opportunity for development. The Calabrian earthquake stirred a new interest in geological phenomena in the Kingdom outside the area immediately near the capital, the Vesuvius and the Phlaegrean Fields. There were reasons 
for this other than scientific curiosity. The Kingdom badly needed natural resources; its territory was extremely worrisome (generally neglected, rich in marshes, poor in roads, with a difficult if nonexistent control of waters), but Calabria promised to be rich in iron and other minerals. In the same years, a large niter (potassium nitrate, saltpeter) cave was discovered in the Pulo (a cavity in the earth, a dolina) near the town of Molfetta, in the Puglie. Niter was a crucial mineral for diverse industrial uses, prominently for the preparation of gunpowder. The monarchy and the scientific and economic community in Naples turned to a foreign (that is, from the Veneto) scholar and geologist, Alberto Fortis, to better exploit the Pulo. While the Calabrian iron industry flourished, even if on a small scale, with the establishment of a ferriera at Mongiana, the Pulo manufacture never materialized. The monarchy also promoted the training of a group of young mineralogists, by sending them abroad (in Austria, Germany, and as far as Scotland) in an ominous year, $1789^{12}$.

It is thus not surprising that the Calabrian earthquake of 1783 - together with mineralogy, and thus chemistry - is one of the main interests in the short-lived journal Giornale Enciclopedico di Napoli (1785-6), the expression of a well-known reformist and freemason group gathering in the salon of the Di Gennaro brothers. Alongside comparatively little information from outside the Kingdom, a striking number of memoirs comes from the provinces, mainly from the Puglie, but also from the Calabrie, from terra di Lavoro, from the Abruzzi. The periodicals published in Naples between the 1780s and the French decade thus support the hypothesis of the importance of journals at a 'local' level, that is, in specific geographic areas and for specific audiences/communities, in this period ${ }^{13}$. Journals (and the scientific information they contained) became more important when provincial communities and phenomena began to be important, that is, when a new consciousness developed of their existence, importance, and of their exploitability in economic terms. The 'advertisement' of foreign science in the course of time acquired an ever stronger political meaning, and it was meant for provincial readers, who might have needed it, as well as for those groups or individuals living in the capital, who preferred to consider themselves as already informed. And there was a conscious effort to 'advertise' provincial science - more on the side of self-advertising or self-promotion - in the capital and beyond (mainly in Italy). Provinces were deemed as foreign to the center as more remote countries - often one gets the impression that they were more or less internal colonies - but they could be useful. Scientific informations were circulated that could be deemed useful - mainly related to economy or technical improvements - and promoting the common good. By far the two best represented disciplines in the journals of the $1780 \mathrm{~s}$ and 1790s are medicine and agriculture, in this order; but reports, besides geology and metallurgy, include antiquarianism and even literature.

In the 1790s, in the Analisi Ragionata de' Libri nuovi (1791-93), ed. by Giovan Leonardo Marugi (1753-1836), followed by the Effemeridi enciclopediche (1794-6) and by the Giornale letterario di Napoli (1793-1799), the latter edited by Luigi Targioni (1751-?) 'promotion' and self-promotion of the Provinces and provincials becomes even more evident, while more and more news also come from European and Italian 'nations', against the backdrop of the changing political landscape and the radicalisation of conflicts. In the Analisi there is not much science (approx 30\% of the articles; the others concern history, politics, philology). If we give a look to the place of printing of the books that are excerpted, we have an extraordinary variety of places, most of them mentioned only once: London (via Turin), London (via Venice), London (via Ticino), Padua, Salzburg, Dublin, Copenhagen, 
Paris, Venice, Florence, St. Petersburg, Pavia, Amsterdam (broadly following the order in which they appear). One gets the impression that in this case 'foreign' science has a slightly redundant or exhortative function - in fact, what seems really important is the way the journal publishes and promotes the circulation of scientific and technical informations from the Provinces and from Naples itself. The Effemeridi are so reactionary that the modern reader is put to the test; the Giornale Letterario, on the contrary, is arguably the most scientifically interesting and rich periodical of its time, the work of an intriguing figure, the Tuscan Luigi Targioni ${ }^{14}$. In the latter, we find again a striking mixture of reports coming from Vienna or Paris and from S. Marco in Lamis, in the Capitanata province; from Venice or London and from Altamura (Terra di Bari) or Grottaminarda (Principato ultra). Again, no specialised journals. The choice of an encyclopedic journal was better suited for provincials and the provinces?

\section{The Giornale Enciclopedico and its encyclopedia}

The Giornale Enciclopedico was founded in 1806, in the very year of the beginning of the 'French decade', and obviously it reflects the political situation in its ambiguous deference to the new rulers, perceived as liberators as much as refused as foreign rulers. Its model, nonetheless, was French - and over the years it was to become the mirror of the intellectual choices of the Murat government and of its efforts towards an effective independence. Its life was never easy. Printers frequently changed over the years, and only in 1817 it was printed on its own. In 1810 publications were interrupted. From the year 1811 onwards the journal appears radically transformed: articles become longer, more articles are gathered under the same subject heading, and there is a tendency to publishing original essays, more than short excerpts, translations or articles from other journals, or news. Beginning with 1814, when the French rule was overturned, the Giornale received a financial support from the government ${ }^{15}$. One of its interesting features is that beginning with the years 1817-1818 (that is, during the Restoration) more and more articles are signed by their authors, abandoning the almost total anonymity that it had maintained throughout the French years. Approximately $50 \%$ of the articles are translated from foreign journals or other publications (e.g. from the Mémoires of the French Académie des Sciences). Turning to the program of the Giornale, already in the first year there is a marked and explicit preference for scientific subjects, with the creation of a disciplinary hierarchy:

"This work is planned following the most noteworthy European journals; and it is devoted to Sciences, Literature and Arts. Amidst many useful topics, the editors will give preference to Natural History, Medicine, Surgery and Agriculture. The Arts, both industrial and imaginative, moral sciences and literature have the second place"16.

11 The Arti industriali include Arti chimiche (practical applications of chemistry to different industries and manufactures, e.g. tipography and painting, sculpture, and the like), Farmacia, Materia medica (medical pharmacy), but also economic disciplines, as Economia pubblica, Economia domestica (household recipes), Economia rurale and Agricoltura. The 'imaginative arts', Arti di immaginazione, are the traditional Letteratura Romanzi Biografia Eloquenza Belle Arti; poetry (Poesia) is mainly represented by bombastic eulogies of Napoleon, his military successes, his family, whose meaning is obviously more political than literary. The section Scienze morali (among which Filosofia Teologia Politica Giurisprudenza Istoria Filologia Antichità) is in fact the richest of the three, especially as 
concerns antiquarianism, one of the recurrent topics of journals, and of cultural life in general, in the South. Scientific headings - among them Istoria Naturale, Botanica, Entomologia, Mineralogia, Metallurgia, Matematica, Geografia, Statistica (mainly reports on medical topography), Fisica, Idraulica, Antropologia, Fisiologia, Anatomia comparata, Medicina, Igiene - are interesting in that by following their 'history' along the years one can follow disciplinary changes as well as the shifting focuses of scientific policy in the Kingdom. Headings (and disciplinary divisions) can be broadly, and rather schematically, classified in 'stable', resisting throughout the issues, disappearing, changing (meaning or contents), and new.

Among stable headings and disciplines, medicine is one of the best represented. Medical reviews and articles are scattered in different sections of the Giornale Enciclopedico, and they outnumber by far articles dealing with other scientific disciplines. Medicine and surgery, as is well known, were a staple of learned journals. The irresistible ascent of surgery - and pharmaceutical chemistry - is a characteristic feature of all European journals of the period. A surprisingly small number of articles, given the hot debates in Italy on this point, deals with medical systems, among them Brownism. On the contrary, it does not come as a surprise that many articles and translations illustrate and refer to the novelties coming from Parisian clinic and physiology - works by Corvisart, Barthez, Dumas, etc. The case of surgery, that had had a long and glorious tradition in the city, dating back to the early 17th century, is striking. The strict relationship between French surgeons of the French Armée and surgeons in Naples, who were among the foremost 'giacobini' in the city and who admired the French tendency to the promotion of surgeons to learned medicine, is exemplified in the two first years by articles dealing with technical details but also with sociability and self-promotion - e.g., the request by Paroisse, surgeon to the King (Giuseppe Bonaparte), for works by military surgeons on the treatment of wounds, or on the medical topography of the city of Naples, with the announcement of a competition for a medal representing the Queen, to be given to the best work on childbirth. After this, surgery disappears altogether from the pages of the Giornale. There are no articles on surgery until 1814, that is, until the Restoration: in this and in the following years a number of articles comment on the works by Michele Troja or describe eye operations. In 1818, a letter by the Neapolitan surgeon Giovanni Battista Quadri - one of the most skilled of his generation and a professor at the Royal Clinical School for Ophtalmology, Regia scuola clinica di Ottalmiatria - to William Somerville describes a goiter operation; Quadri contributes other works to the Giornale. Surgery is only well represented among medical disciplines in the Giornale Enciclopedico in its later years; it is thus not surprising that Chirurgia (surgery) is not to be found as an independent heading in the first years of the journal. This may well be a move against the separation between medicine and surgery, but it could be, and it probably is, a conscious choice, along the line of the promotion of other 'practical arts' in the Murat era and maybe of an effort to quench the political extremism of many a professional surgeon.

Medicine continued to be present throughout the life of the Giornale, but medical subdisciplines or specialisations changed, sometimes dramatically. This is what happens to Polizia Medica, the peculiar version of public health developed at the end of the $18^{\text {th }}$ century in works such as those by Johann Peter Frank. Some headings disappear because the disciplines they represent have changes status, becoming too specialized or not yet popular in their 'new' version: this is the case of Antropologia and Fisiologia (under this heading an unnamed author, probably Giosue Sangiovanni, published in 1809 a lengthy 
review of Lamarck's Philosophie Zoologique ${ }^{17}$ ). In the first years of publication a substantial number of translated reviews and excerpts from other European journals deal with this topic, but it soon declines and wanes away. During the French decade provisions for public health were an important concern of the government ${ }^{18}$ : this is probably a case of a discipline that is not any more perceived as up-to-date by the professional public of medics. In fact, later on the heading Igiene (hygiene) takes its place. Nevertheless, the best example of a 'lost' heading in the Giornale is Istoria Naturale, that significantly disappears after the first few years, along the lines of the European loss of interest in a 'general' natural history on the model of Buffon, with the emergence of specialised disciplines. Along the same lines, Arti chimiche (a practical discipline) is transformed into Chimica.

Many new headings and topics are heirs to the previous Istoria Naturale. In 1813, for instance, the heading Geologia applies to articles by Andrea Savaresi on volcanoes. But the most spectacular case is Biologia, appearing from 1817 onwards and containing some of the best original articles published in the journal, also representing a meaningful sample of the state of the art in Italian life sciences in the age of transformism. This does not simply mean that there are shifts in the disciplines themselves, and that the journals reflect these changes. As the case of Biologia well shows, journals are often actively used to advertise and promote these changes (as well as personal reputations).

\section{Two case histories: botany and Biologia}

15 To illustrate the latter point, we can turn very briefly to two cases, one from the very first years of life of the Giornale Enciclopedico, the other from its last years. They are useful in illustrating how the journal was used to exploit the shifting boundaries between disciplines, as well as to enhance reputations. The botanist Michele Tenore (1780-1861) is a well-known figure in Neapolitan - indeed Italian - science in the first half of the 19th century. He was educated in medicine, but he is known as the founder of Naples Orto Botanico, the botanical garden, one of the various cultural and scientific institutions promoted in the French decade. Before finding an appropriate location in 1807 near the 'new' $18^{\text {th }}$ century avenue of Via Foria (where it still exist), the Orto was first housed in an old cloister, in Monteoliveto. The Giornale Enciclopedico was published nearby, and Michele Tenore was in fact one of its main, if not the main, contributors in its first years of life. Besides the many reviews of his works, the Giornale also printed or pre-printed his own articles (some of them signed). He slowly moved from describing the medicinal powers of some samples of the the Neapolitan flora to a wider project, a comprehensive description of the plants in the Kingdom of Naples; the growth and ultimate success of the project can be followed through the pages of the Giornale.

One of the first articles by Tenore is published in 1807 under the heading Materia medica; he states that he wants to provide for the necessities of apothecaries in the provinces by offering news on medicinal plants. The next time we find his work mentioned is in 1809 , in the Annunzj Letterari, that is, in the miscellaneous news. The third time, still in 1809, he is writing under Storia Naturale, publishing news on an angelfish, a small kind of shark. Both Tenore and his specialisation are moving away from medicine proper, and from its practical purposes, to natural history. The word Botanica as a specific heading only appears in 1809, in an article which is not signed - but possibly comes once again from Tenore, and deals with how to conduct practical herborization. In fact, much later, in the 1830s, Michele Tenore wrote some interesting and well-known reports on his herboristic 
expeditions in the Kingdom, also rich in geological and anthropological informations. Sergio Sabato has studied the strategy of Tenore in publishing the first issues of his main work, the comprehensive and beautifully illustrated Flora Napolitana $(1811-1838)^{19}$. This work was not only announced in the Giornale Enciclopedico; Tenore used a complex interplay between anonimity and signed articles (not only by him, but also by his students) to promote his work. Tenore also hoped to exploit his discoveries - not only for helping apothecaries, but in order to promote Neapolitan manufacture and industry. He expounded the virtues of 'indigenous' plants, that could substitute for imported ones. This is apparent in his participation to the discussion - in several articles in the years 1810-1811 - of the possibility of using guado, woad, as a fit substitute for indigo.

Another interesting case of the combination of self-promotion with disciplinary change comes from the last years of the Giornale Enciclopedico, broadly from 1817 to 1821, when the physician Luigi Chiaverini (1777-1834) became one of its main contributors. His biography is meaningful: a provincial, born in the Abruzzi, Chiaverini had been educated in Naples and in the first years of the $19^{\text {th }}$ century he had moved to Paris. Back in the Kingdom, he became a celebrated professor of medicine at the university. Among other works, he published in the Giornale a lengthy essay on the Fondamenti della Biologia comparativa (Foundations of Comparative Biology) that shows how influenced he was by French theories on life, comparative anatomy and zoology, but also by 'local' theories on human history and its vicissitudes - he repeatedly quotes Giovan Battista Vico, whose work was enjoying a renaissance in the same years. Chiaverini also wrote on medical history, a discipline represented in the Giornale and that was slowly emerging as an independent branch of historical research, with an appeal for medics. In the late 1820s he vainly tried to obtain by the government permission and funds to travel abroad - in Germany - for scientific purposes.

His notion of Biologia comparativa is that it should be a general and comprehensive maybe too general, and too systematic - theory of physical development of the animals. Chiaverini loved systems, broad classifications, and outlandish terminology; in a review of a work by his colleague Benedetto Vulpes, published in 1818 in the Giornale, he criticizes Vulpes' timidity in not attempting to transform Patologia Generale, general pathology, in a new and wider discipline, what Chiaverini proposes to call Biologia igiologica, hygiologic biology. This is obviously not the place to discuss Chiaverini's work; what is interesting is the way he uses the Giornale to promote 'his' new discipline and its articulations. In one biography, rather unreliable, it is said that Chiaverini had suggested the term biologie to no less than Jean-Baptiste Lamarck, while staying in France and assisting to his lessons at the Jardin des Plantes ${ }^{20}$. Despite these nationalistic claims, or phantasies, and even outside the Giornale or the Kingdom of Naples, the urge to create and transform scientific terminology was by this time widely felt, also in order to free Italian science from what was perceived as an unduly dominant attitude of the French language. Biologia, in Chiaverini's view, was meant as a substitute for Anatomia comparativa, Fisica and Fisiologia, and even for Medicina and Antropologia; all of which were used to denote 'general' discussions on the living organisms. But he was not only promoting a new discipline: by using this up-to-date terminology, and expanding it to cover almost all medical fields, he also was exploiting the arena of the Giornale Enciclopedico to exhibit his participation to scientific life and discussions at a European level. 


\section{Conclusions}

19 In Naples, attention brought to the backward Provinces acquired a political meaning, reflected in the journals published in the pre-revolutionary period. During the French decade, when the Kingdom became a part of the Napoleonic empire, the movement was towards a reappropriation of the journals by the scientific élite, wishing to promote a new and centralised system of the sciences and of scientific institutions, with strong practical and economic implications. This ideology was embodied in institutions such as the Regio Istituto di Incoraggiamento, proposed by Giuseppe Bonaparte in 1806 and founded in 1808, following French - and indeed English - models. This was originally meant for the study of Natural History, but it rapidly changed to an academy aimed at the scientific and technical and economical advancements in the Kingdom; its life and its publications were connected to the Giornale Enciclopedico, that often published preprints or works by its members. The analysis of learned periodicals published in Naples between the end of the $18^{\text {th }}$ and the beginning of the $19^{\text {th }}$ century - with a special focus on medicine and related sciences - shows that despite the predominance of French influence, the learned community in the Kingdom adopted and discussed a number of technical and theoretical innovations coming from all over Europe. Novelties and results were described in the journals and discussed - including such topics as Scottish surgical techniques, Gall's phrenology, Austrian doctrines on public health, Lamarck's and Cuvier's zoology and 'biology', German medical history. The dissemination of news produced an active participation to broad European discussions, notably in the fields of public health, surgery and pharmacology, also encouraging discussion and research in the fields of zoology, comparative anatomy, geology and topography, and their relation to medical sciences. In the journals we have been mentioning an evolution can be observed from an almost passive reception of foreign news and articles to the active reappraisal of topics and news. Parallel to this movement is the larger participation of local authors (in this case, mainly provincial doctors and other learned men) to the communication means represented by scientific and professional journals. This is obviously a pattern common to other European journals - and in the long run it also meant a move towards specialization. In Naples it can also be read as an effort to extend the network of scientific communication to the Provinces - also extending the number of readers and indeed authors of the journals. The encyclopedic project had a strong a political meaning, and the specialized journal would have probably required better organized professional groups; they did not develop before the 1820s, despite previous abortive attempts. Journals, and especially the Giornale Enciclopedico, embody encyclopedias with a purpose: the reorganisation of disciplinary fields, political and ideological (and thus professional) statements.

Journals, as other institutions, did not grow in isolation; they are the product of what could be called a 'cloud', with an anachronism taken from recent developments in information technology. The late $18^{\text {th }}$ and early $19^{\text {th }}$ century 'cloud' of was composed mainly by printed matter: encyclopedias, dictionaries, academic acts, booklets, pamphlets, translations and so on and so forth. When defining the geography or contents of the circulation of scientific informations in this period the 'cloud' and the way the press is used at a local level becomes absolutely crucial (and it may also become a nightmare for the historian trying, e.g., to find out who is the author of what). It is 
apparent that in Naples - as elsewhere - journals, but also translations, compilations, additions to technical and scientific literature coming from abroad and reprinted in the city, were used in this period by disciplinary communities and upwards mobile professionals, that often were medical men. The same individuals were readers and authors at the same time. These were the 'middling' practitioners who could very easily turn journalists and pubblicisti. In fact, Marugi and Targioni are physicians, as are Tenore and Chiaverini, shrewdly exploiting different means of communication in order to promote sciences, political ideology, or both.

\section{NOTES}

1. Un foglio periodico deve esse.re un termometro politico che di tempo in tempo mostri lo stato del popolo; in questo aspetto il suo dovere è sacro, ed i sforzi di coloro che vi travagliano devono meritare la riconoscenza pubblica.

2. A biography in Pasquale ALBINO, Biografie e ritratti degli uomini illustri della provincia di Molise, vol.

III, Campobasso 1866, p. 55-59.

3. Raffaele PEPE, "Varieta di economie rurale", Giornale Enciclopedico, Agosto 1806, p.131.

4. Giornale economico rustico di Molise, founded in 1819.

5. See Girolamo imbruglia (ed.), Naples in XVIII century. The Birth and Fall of a Nation, Cambridge University Press, 2000; John ROBERTSON, The Case for Enlightenment. Scotland and Naples 1680-1760, Cambridge University Press, 2005; John A. Davis, Naples and Napoleon. Southern Italy and the European Revolutions, 1780-1860, Oxford University Press, 2006; Antonio BORRELLI, Istituzioni scientifiche medicina e società. Biografia di Domenico Cotugno (1736-1822), Firenze, Olschki, 2000

6. Anna Maria RAO, Esuli. L'emigrazione politica italiana in Francia (1792-1802), Napoli, Guida ed., 1992.

7. Anna Maria RAO, Note sulla stampa periodica, in Anna Maria Rao (ed.), Editoria e cultura a Napoli nel XVIII secolo, Napoli, Liguori 1998, p. 336-337.

8. Patrizia DELPIANO, I periodici scientifici nel Nord Italia alla fine del Settecento: studi e ipotesi di ricerca, Studi Storici, 30, 1989, p. 457-482.

9. Ana Maria RAO, Mercato e privilegi: la stampa periodica, in Editoria e cultura, op. cit., p. 173-199.

10. Napoli non ha un Giornale. Noi non vogliamo dire né che lo meriti, né che ne abbia bisogno. Ne han bisogno certamente le Province, nelle quali siccome non si trovano se non picciole città, $i$ dotti e gli amatori che vi sono isolatissimi, non possono comunicare col rimanente non diremo dell'Europa, non dell'Italia, ma del Regno istesso, se non per mezzo di un Giornale. Sia dunque il nostro Giornale destinato a servir di mezzo da trasmettere lo straniero ai nostri, il nostro ai nostri stessi, ed agli stranieri, Analisi ragionata, gennaio 1793, Prefazione.

11. From 1792 to 1793 the physician and chemist Vincenzo Comi published Il commercio scientifico d'Europa col Regno delle Due Sicilie in Teramo (Abruzzi).

12. Maria toscano, Alberto Fortis nel Regno di Napoli: naturalismo e antiquaria 1783-1791, Bari, Cacucci, 2004.

13. See the forthcoming volume ed. by Jeanne PEIFFER and Jean-Pierre VITTU, Scholarly journals in early modern Europe. Communication and the construction of knowledge.

14. Renato PASTA, Scienza politica e rivoluzione. L'opera di Giovanni Fabbroni (1752-1822) intellettuale e funzionario al servizio dei Lorena, Firenze, Olschki, 1989, p. 231 (n. 13). 
15. Quest'opera periodica, che il Governo degnasi d'incoraggiare generosamente, Giornale Enciclopedico, Avviso, 1814 (VIII), cover.

16. Questa opera è disegnata sul piano dei più grandi Giornali di Europa, ed è destinata alle Scienze, alla Letteratura ed alle Arti. Fra tanti utili oggetti $i$ compilatori danno sempre la preferenza alla storia della Natura, alla Medicina, alla Chirurgia ed all'Agricoltura. Anno il secondo luogo le Arti, tanto industriali che d'immaginazione, le scienze morali e la letteratura. Giornale Enciclopedico, Avviso, 1806 (I), cover.

17. See Pietro CORSI, Lamarck en Italie, "Revue d'histoire des Sciences", 37, 1984, p. 47-64.

18. Brigitte MARIN, Poverty, health and Hospitals in Naples in the $18^{\text {th }}$ and $19^{\text {th }}$ centuries, in Ole Peter Grell, Andrew Cunningham and Bernd Roeck (ed.), Health Care and Poor Relief in $18^{\text {th }}$ and $19^{\text {th }}$ Century Southern Europe, Aldershot, Ashgate, 2005, p. 208-228.

19. Sergio SABATO, Remarks on the publication dates of Tenore's Flora Napolitana, "Taxon", 39 (1990), 3, p. 409-416.

20. Biblioteca Nazionale di Napoli, ms. XIV.H.4, Antonio Beatrice, Necrologia di Luigi Chiaverini.

\section{ABSTRACTS}

The paper deals with learned journals in Naples at the end of the $18^{\text {th }}$ century and with their political meaning, especially in relation to the promotion of the Provinces of the Kingdom. The 'encyclopedia', the system of organisation of the different sections of knowledge, in the Giornale Enciclopedico (1806-1821) and in other periodicals, reflects political implications, conflicts and tensions in the field of sciences - sciences as intellectual pursuits as well as practices - in the Kingdom of Naples in the years preceding and following the 1799 Revolution. By following the way headings and sections change, it is possible to examine the different patterns of appropriation by individuals and groups acting in the Kingdom - and also following, and indirectly describing, the changes in the wider European classification of sciences and disciplines.

À la fin du $18^{\mathrm{e}}$ siècle, les journaux savants occupent une position centrale dans les dynamiques politiques napolitaines. Ils jouent particulièrement une fonction majeure dans la circulation des informations et, par le biais de la réputation de leurs rédacteurs, dans les processus de promotion symbolique des différentes provinces du Royaume. L'idéal encyclopédique, le système d'organisation des différentes sections des savoirs dans le Giornale Enciclopedico (1806-1821) et dans d'autres périodiques savants, permettent de mieux saisir les enjeux politiques des dynamiques scientifiques. Elle met au jour le rôle joué par les sciences dans les conflits politiques et les tensions sociales qui agitent le Royaume de Naples autour des années précédant et suivant la révolution de 1799. En analysant finement l'organisation éditoriale du journal, les mutations des rubriques et des titres des sections, il est possible d'examiner les modalités d'appropriation des sciences par les individus et les groupes investis dans les dynamiques politiques du Royaume et, ainsi, de s'interroger sur l'impact d'un périodique encyclopédique au-delà du monde des sciences. 
INDEX

Keywords: Learned periodicals, Encyclopedic journals, Kingdom of Naples, Scientific taxonomy (or classification), Politics of science

\section{AUTHOR}

MARIA CONFORTI

Sezione di Storia della Medicina

Sapienza Università di Roma 